\title{
Genital immunization of heifers with a glycoprotein E- deleted, recombinant bovine herpesvirus 1 strain confers protection upon challenge with a virulent isolate ${ }^{1}$
}

\author{
Marcelo Weiss ${ }^{2}$, Fernanda S. F. Vogel ${ }^{2}$, Mathias Martins ${ }^{2}$, Rudi Weiblen², \\ Paulo M. Roehe ${ }^{3}$, Ana Cláudia Franco ${ }^{4}$ and Eduardo Furtado Flores ${ }^{2 *}$
}

ABSTRACT.- Weiss M., Vogel F.S.F., Martins M., Weiblen R., Roehe P.M., Franco A.C. \& Flores E.F. 2010. Genital immunization of heifers with a glycoprotein E-deleted, recombinant bovine herpesvirus 1 strain confers protection upon challenge with a virulent isolate. Pesquisa Veterinária Brasileira 30(1):42-50. Departamento de Medicina Veterinária Preventiva, Universidade Federal de Santa Maria, 97105-900 Santa Maria, RS, Brazil. E-mail: eduardofurtadoflores@gmail.com

Venereal infection of seronegative heifers and cows with bovine herpesvirus type 1.2 (BoHV-1.2) frequently results in vulvovaginitis and transient infertility. Parenteral immunization with inactivated or modified live BoHV-1 vaccines often fails in conferring protection upon genital challenge. We herein report an evaluation of the immune response and protection conferred by genital vaccination of heifers with a glycoprotein E-deleted recombinant virus (SV265gE-). A group of six seronegative heifers was vaccinated with SV265gE- $\left(0,2 \mathrm{~mL}\right.$ containing $\left.10^{6.9} \mathrm{TCID}_{50}\right)$ in the vulva submucosa (group IV); four heifers were vaccinated intramuscularly (group IM, $1 \mathrm{~mL}$ containing $10^{7.6} \mathrm{TCI}_{50}$ ) and four heifers remained as non-vaccinated controls. Heifers vaccinated IV developed mild, transient local edema and hyperemia and shed low amounts of virus for a few days after vaccination, yet a sentinel heifer maintained in close contact did not seroconvert. Attempts to reactivate the vaccine virus in two IV vaccinated heifers by intravenous administration of dexamethasone $(0.5 \mathrm{mg} / \mathrm{kg})$ at day $70 \mathrm{pv}$ failed since no virus shedding, recrudescence of genital signs or seroconversion were observed. At day $70 \mathrm{pv}$, all vaccinated and control heifers were challenged by genital inoculation of a highly virulent BoHV-1.2 isolate (SV$56 / 90,10^{7.1} \mathrm{TCID}_{50}$ /animal). After challenge, virus shedding was detected in genital secretions of control animals for 8.2 days (8-9); in the IM group for 6.2 days (4-8 days) and during 5.2 days (5-6 days) in the IV group. Control non-vaccinated heifers developed moderate (2/4) or severe (2/4) vulvovaginitis lasting 9 to 13 days (x: 10.7 days). The disease was characterized by vulvar edema, vulvo-vestibular congestion, vesicles progressing to coalescence and erosions, fibrino-necrotic plaques and fibrinopurulent exudate. IM vaccinated heifers developed mild (1/3) or moderate (3/4) genital lesions, lasting 10 to 12 days (x: 10.7 days); and IV vaccinated heifers developed mild and transient vulvovaginitis (3/4) or mild to moderate genital lesions (1/4). In the IV group, the clinical signs lasted 4 to 8 days (x: 5.5 days). Clinical examination of the animals after challenge revealed that vaccination by both routes conferred some degree of protection, yet IV vaccination was clearly more effective in reducing the severity and duration of clinical

\footnotetext{
${ }^{1}$ Received on July 7, 2009.

Accepted for publication on August 19, 2009.

2 Setor de Virologia, Departamento de Medicina Veterinária Preventiva, Universidade Federal de Santa Maria, Avenida Roraima 1000, Cidade Universitária, Bairro Camobi, Santa Maria, RS 97105-900, Brazil. ${ }^{*}$ Corresponding author: eduardofurtadoflores@gmail.com
}

\footnotetext{
${ }^{3}$ Virologia, Instituto de Pesquisas Veterinárias Desidério Finamor, Fepagro Saúde Animal, Estrada do Conde 6000, Eldorado do Sul, RS 92990-000, Brazil.

4 Departamento de Microbiologia, Instituto de Ciências Básicas da Saúde, Universidade Federal do Rio Grande do Sul, Av. Sarmento Leite 500 , Porto Alegre, RS 90050-170, Brazil.
} 
disease. Furthermore, IV vaccination reduced the period of virus shedding in comparison with both groups. Taken together, these results demonstrate that $S V 265 \mathrm{gE}$ - is sufficiently attenuated upon IV vaccination in a low-titer dosis, is not readily reactivated after corticosteroid treatment and lastly, and more importantly, confers local protection upon challenge with a high titer of a virulent heterologous BoHV-1 isolate. Therefore, the use of this recombinant for genital immunization may be considered for prevention of BoHV1 -associated genital disease in the field.

INDEX TERMS: Bovine herpesvirus, BoHV-1.2, vulvovaginitis, genital infection, latency, reactivation.

RESUMO.- [Imunização genital de bezerras com uma cepa recombinante do herpesvírus bovino tipo 1 defectiva na glicoproteína $E$ confere proteção frente a desafio com um isolado virulento.] A infecção genital de novilhas ou vacas soronegativas pelo herpesvírus bovino tipo 1.2 (BoHV-1.2) pode resultar em vulvovaginite e infertilidade temporária. As vacinas atenuadas ou inativadas administradas pela via parenteral freqüentemente conferem proteção incompleta frente a desafio pela via genital. Este estudo relata uma avaliação da resposta imunológica e proteção conferida pela vacinação genital de bezerras soronegativas com uma cepa recombinante do BoHV-1 defectiva na glicoproteína E (SV265gE-). Um grupo de seis bezerras foi vacinado com a cepa SV265gE$\left(0,2 \mathrm{~mL}\right.$ contendo $\left.10^{6,9} \mathrm{TCID}_{50}\right)$ na submucosa da vulva (grupo IV); quatro bezerras foram vacinadas pela via intramuscular (IM; dose $10^{7,6} \mathrm{TCID}_{50}$ ) e quatro bezerras permaneceram como controles não-vacinadas. As bezerras vacinadas pela via IV apresentaram edema e hiperemia leve e transitório na vulva e excretaram vírus em títulos baixos por alguns dias após a vacinação, porém uma bezerra soronegativa mantida em contato não soroconverteu. Administração de dexametasona pela via intravenosa no dia $70 \mathrm{pv}(0,5 \mathrm{mg} / \mathrm{kg})$ em duas bezerras vacinadas pela via IV não resultou em excreção viral, recrudescência clínica ou soroconversão. No dia 70pv, as bezerras vacinadas e as controle foram desafiadas pela inoculação genital da cepa de BoHV-1.2 altamente virulenta SV$56 / 90$ (10 $10^{7.1} \mathrm{TCID}_{50}$ /animal). Após o desafio, excreção viral nas secreções genitais das bezerras controle foi detectada por 8,2 dias (8-9); no grupo IM durante 6,2 dias (4-8 dias) e durante 5,2 dias (5-6) nas bezerras do grupo IN. As bezerras do grupo controle desenvolveram vulvovaginite moderada (2/4) a severa (2/4) que duraram entre 9 e 13 dias (x: 10,7 dias). A doença se caracterizou por edema vulvar, congestão vulvo-vestibular, formação de vesículas/pústulas que coalesceram, erosões, placas fibrino-necróticas e exsudato fibrino-purulento. As bezerras do grupo IM desenvolveram lesões genitais leves (1/ 3) a moderadas (3/4), com duração de 10 a 12 dias (x: 10,7 dias). No grupo IV, as bezerras desenvolveram vulvovaginite leve e transitória (3/4) ou lesões moderadas (1/4), com duração de 4 a 8 dias (x: 5,5 dias). O exame clínico desses animais após o desafio demonstrou que a vacinação, independentemente da via de administração, conferiu proteção e que, a vacinação IV mostrou-se mais efetiva na redução da severidade e duração da do- ença clínica. A vacinação IV também determinou uma redução significativa no período de excreção viral após desafio, em comparação com os grupos controle e IM. Esses resultados demonstram que a cepa $S V 265 \mathrm{gE}$ - administrada pela via IV confere proteção satisfatória frente a desafio local com um isolado heterólogo de BoHV-1 altamente virulento. Além disso, a cepa vacinal é atenuada para vacinação IV em baixos títulos e não é reativada facilmente após administração de dexametasona. Assim, a utilização da cepa recombinante para imunização genital pode se constituir em alternativa para prevenir a infecção e doença reprodutiva associada com o BoHV-1.

TERMOS DE INDEXAÇÃO: Herpesvírus bovino, BoHV-1.2., vulvovaginite, infecção genital, latência, reativação.

\section{INTRODUCTION}

Bovine herpesvirus 1 (BoHV-1) is an important alphaherpesvirus of cattle, associated with a variety of clinical manifestations including respiratory disease (infectious bovine rhinotracheitis, IBR), genital disease (balanopostitis/ vulvovaginitis, IBP/IPV), abortions, multisystemic infection of neonates and, occasionally, neurological disease (Roizman 1992, Kahrs 2001). BoHV-1 infection has a worldwide distribution with the exception of some European countries which undertook eradication programs (Ackermann \& Engels 2006). An important biological property of animal and human alphaherpes-viruses - which plays a pivotal role in the perpetuation of these viruses in nature is the ability to establish lifelong latent infections in sensory nerve ganglia (Rock 1994).

Field isolates of BoHV-1 belong to the same serotype and therefore cannot be distinguished serologically by routine serological methods (Bratanich et al. 1991). Nonetheless, molecular and antigenic differences detected by restriction enzyme analysis (REA) and monoclonal antibody binding have allowed the classification of BoHV1 in two main subtypes, BoHV-1.1 and BoHV-1.2 (Metzler et al. 1985, Bulach \& Studdert 1990). The isolates classified as BoHV-1.1 have been more frequently associated with respiratory disease (IBR) and represent the predominant subtype in Europe and North America (Metzler et al. 1986). In contrast, viruses belonging to the BoHV-1.2 subtype have been more often associated with genital disease (IPB/ IPV), are not highly prevalent in Europe and North America yet represent a considerable proportion of South American isolates (Suarez-Heinlen et al. 1993, D’Arce et al. 2002). 
In spite of possible preferences (or tropism) for the respiratory or reproductive tract, the association of each subtype with the respective clinical syndrome appears not to be mutually exclusive (Metzler et al. 1986, SuarezHeinlen et al. 1993, D'Arce et al. 2002).

A number of inactivated and modified live vaccines (MLV) attenuated by conventional methods or by genetic manipulation have been developed and used for controlling BoHV-1 infection and disease worldwide (van Drunen Littel-van den Hurk 2006). In general, MLV vaccines induce a rapid, long-lasting immune response and mucosal immunity as well, but are less safe than killed vaccines (van Drunen Littel-van den Hurk 2006). On the other hand, whole inactivated virus or subunit vaccines induce immunity in lower levels and generally of short duration, yet are safe for different categories of cattle (van Drunen Littel-van den Hurk et al. 1993, van Drunen Littel-van den Hurk 2006). In a search for a more solid immune response, a number of MLV vaccines for intranasal (IN) administration have been tested and some are currently available commercially (Todd et al. 1971, Zygraich et al. 1975, van Drunen Littel-van den Hurk 2006). Regardless the type (inactivated, subunit or MLV), the concept of vaccines with antigenic markers (also known as differential vaccines, DIVA) for BoHV-1 control and/or eradication became a consensus in the last decades (van Drunen Littel-van den Hurk 2006). In this sense, the non-essential viral glycoprotein $\mathrm{E}(\mathrm{gE})$ appears to represent one of the most suitable antigenic markers for such vaccines (Kaashoek et al. 1995).

Using a BoHV-1.2 virus isolated from an outbreak of respiratory disease in Southern Brazil as background, our group reported the construction of a gE-deleted BoHV-1 (SV265gE-) to be used as a vaccine strain (Franco et al. 2002a). This recombinant virus was subsequently shown to be attenuated for calves after IN and intramuscular (IM) administration and conferred protection against homologous virus challenge (Franco et al. 2002b). Subsequent studies investigated the transmission of this virus under field conditions and demonstrated its safety for pregnant cows (Spilki et al. 2005).

Genital disease (vulvovaginitis, balanopostitis) associated with BoHV-1 infection has been frequently reported among Brazilian cattle (Weiblen et al. 1992, 1996). Likewise, a considerable number of Brazilian and Argentinean BoHV-1 isolates were shown to belong to the BoHV-1.2, the subtype more commonly associated with genital disease (D'Arce et al. 2002, Suarez-Heinlen et al. 1993). Nevertheless, none of the vaccines currently available in the country has been tested regarding to genital protection.

Thus, the present experiment was designed to evaluate the attenuation and protection conferred by the recombinant Brazilian BoHV-1 strain SV265gE- after genital immunization. We also investigated the ability of the recombinant strain to reactivate from latent infection in IV-vaccinated heifers. Our results showed that the candidate vaccine strain is attenuated upon genital inoculation, does not reactivate easily from latency and is able to confer satisfactory protection against genital challenge with a highly virulent heterologous virus. In the context of field circulation of genital isolates, the recombinant strain SV265gE- and the immunization strategy may be useful to prevent the losses caused by BoHV-1 infection in Brazil.

\section{MATERIALS AND METHODS}

\section{Experimental design}

Fourteen BoHV-1 seronegative heifers were used in this experiment. Six animals were vaccinated with the recombinant BoHV-1 strain (SV265gE-) in the submucosa of the vulva (group IV); four were vaccinated intramuscularly (group IM) and another group remained as non-vaccinated controls (control group). Following vaccination, the animals were submitted to clinical, virological and serological monitoring. Sixty five days after vaccination (pv), two heifers from group IV were submitted to dexamethasone ${ }^{5}$ (Dx) administration and monitored thereafter. At the same day, the other 12 animals were challenged by intravaginal inoculation of a BoHV-1 virulent isolate. Following challenge, the animals were monitored on a daily basis for clinical signs and virus shedding during 14 days. Serology was performed on serum samples collected at days 14,30 and $65 \mathrm{pv}$ (the day of challenge); and at days 14 and 30 post-challenge (pc).

\section{Cells and viruses}

All procedures of virus amplification, quantitation, isolation from secretions and virus-neutralizing (VN) assays used a MDBK-derived cell line named CRIB (Flores \& Donis 1995). The cells were cultured on minimal essential medium (MEM), containing ampicillin (1.6mg/L), streptomycin $(0.4 \mathrm{mg} / \mathrm{L})$, amphotericin $(2 \mathrm{mg} / \mathrm{L})$, supplemented with $10 \%$ fetal bovine serum ${ }^{6}$. The production and characterization of the vaccine candidate strain SV-265gE- has been described previously (Franco et al. 2002a, Spilki et al. 2005). The virus used for challenge (SV-56/ 90) was isolated from an outbreak of balanoposthitis in bulls in Southern Brazil (Weiblen et al. 1992) and subsequently characterized as belonging to BoHV-1.2 subtype (D'Arce et al. 2002). The virulence of this isolate has been demonstrated after intrapreputial inoculation of bulls (Vogel et al. 2004) and following intravaginal inoculation of heifers (Henzel et al. 2008).

\section{Animals, immunization, dexamethasone (Dx) treatment and} challenge

All heifers were 8-to-10 month-old and tested negative for BoHV-1 antibodies by VN prior to the experiment. Six heifers were immunized by administration by needle injection of $200 \mu \mathrm{L}$ of a virus suspension containing $10^{6,9} \mathrm{TCID}_{50}$ of the virus strain SV-265gE- into the submucosa of the vulva (bilaterally, $100 \mu \mathrm{L}$ in each side, group IV).

Four heifers were immunized by the intramuscular (IM) route (dose per animal: $10^{7,6} \mathrm{TCID}_{50}$, group IM) and four animals remained as non-vaccinated controls (inoculated with $200 \mu \mathrm{L}$ of MEM in the vulva). Sixty five days post vaccination (pv), two

\footnotetext{
${ }^{5}$ Decadronal@, Aché Laboratórios Farmacêuticos, SA., Via Dutra Km 22, Guarulhos, SP.

${ }^{6}$ Cultilab, Rua José Cristóforo 51, Campinas, SP.
} 
heifers of the IV group (\#237 e \#242) were submitted to dexamethasone (Dx) administration (a single intravenous dose of $0,5 \mathrm{mg} / \mathrm{kg}$ (Winkler et al. 2000). At the same day, the other 12 heifers were submitted to challenge with the isolate SV56/90 (titer: $10^{7,1} \mathrm{TCID}_{50}$ /animal). The challenge was performed by applying the virus suspension with the help of cotton swabs over the internal face of the vulva and vestibulum, bilaterally, followed by a mild friction to spread the inoculum. All procedures of animal handling and experimentation were conducted under veterinary supervision and according to recommendations by the Brazilian Committee of Animal Experimentation (COBEA, law \#6.638 of May 8, 1979). The experiment was approved by an Institutional Animal Ethics Committee (UFSM, approval \# 48/2006).

\section{Animal monitoring, sample collection and processing}

The inoculated animals were monitored on a daily basis through genital examination and body temperature measurements during 14 days following vaccination and for 14 days after Dx treatment or challenge. Genital secretions collected with the help of cotton swabs and immersed in $1 \mathrm{~mL}$ MEM were collected daily from day 0 (day of vaccination) to day $14 \mathrm{pv}$; and from day 65 (day of challenge) to day 14 post-Dx or postchallenge (pc). The swabs were vortexed vigorously, low-speed centrifuged and the supernatants were inoculated onto CRIB cells monolayers and submitted to three passages of five days each. The infectivity of the samples that were positive for virus were subsequently quantified by limiting dilution, the titers were calculated according to Reed \& Muench (1938) and expressed as $\log _{10} \mathrm{TCID}_{50} / \mathrm{mL}$.

Blood samples for serology were collected at days 0 (vaccination day), days 14, 30 and 65 pv (challenge/Dx), 14 and 30 pc. Serum samples were submitted to a standard VN assay, testing two-fold dilutions of sera against a fixed dose $\left(100-200 \mathrm{TCID}_{50}\right)$ of the homologous virus. The virus titers, expressed as the reciprocal of the highest dilution that prevented virus replication, were transformed in GMT (geometric mean titer [Thrusfield 1986]) for the calculation of the mean antibody titers of each group. Sera collected at days $65 \mathrm{pv}$ and 30pi were tested for anti-gE antibodies by using an anti-gE antibody kit (bovine rhinotracheitis virus gE antibody test kit; IDEXX, Maine, USA).

Following challenge (and after Dx treatment of two IV vaccinated heifers) the animals were submitted to daily clinical examinations. The clinical examination was conducted independently by two veterinarians who were not aware of the experimental groups. The clinical parameters observed were: rectal temperature, swelling of the vulva, color of the genital mucosa, presence and diameter of vesicles and pustules; presence, abundance and nature of genital secretion, number and diameter of ulcerations/erosions of the genital mucosa, hemorrhages. Each clinical parameter received a score ranging from or $0,5(+)$ to $4,0(++++)$. At the final of the daily examination, each animal received an individual clinical score considering the overall clinical disease at that particular day. In this way, an objective clinical score could be obtained. The duration of clinical disease for each animal and group considered the days in which the animal (or the group) presented a clinical score $>0,5$.

\section{Statistical analysis}

The duration of virus shedding and clinical disease in IV, IM and control groups were compared statistically by submitting the means of each group to analysis of variance followed by Tukey test with a confidence interval of 0.05 .

Table 1. Serological response post-vaccination (pre-challenge), viral shedding, clinical findings and serological response post-challenge in heifers previously vaccinated (IM, IV) with the recombinant strain SV265gE- or non-vaccinated

\begin{tabular}{|c|c|c|c|c|c|c|c|c|c|}
\hline \multirow{2}{*}{\multicolumn{2}{|c|}{ Group/Heifer }} & \multirow{2}{*}{\multicolumn{2}{|c|}{$\frac{\text { Pre-challenge }}{\text { Antibodies }^{\mathrm{a}}}$}} & \multicolumn{6}{|c|}{ Post-challenge (or post-Dx ${ }^{b}$ ) } \\
\hline & & & & \multirow{2}{*}{\multicolumn{2}{|c|}{$\frac{\text { Virus shedding }}{\text { Duration (days) Titer }(\max )^{\mathrm{c}}}$}} & \multicolumn{2}{|c|}{ Vulvovaginitis } & \multicolumn{2}{|c|}{ Antibodies $^{\mathrm{d}}$} \\
\hline & & VN & ELISA & & & Severity & Days & VN & ELISA \\
\hline \multirow[t]{5}{*}{ Control } & 198 & $<2$ & - & 8 & 5,5 & Moderate & $1-9$ & 8 & + \\
\hline & 202 & $<2$ & - & 8 & 5,9 & Severe & $1-13$ & 4 & + \\
\hline & 230 & $<2$ & - & 9 & 5,8 & Moderate & $2-10$ & 8 & + \\
\hline & 236 & $<2$ & - & 8 & 5,8 & Severe & $1-14$ & 8 & + \\
\hline & & & & $\bar{x} 8,2$ & & & $\bar{x} 11,2$ & & \\
\hline \multirow[t]{5}{*}{ Group IM } & 240 & 2 & - & 8 & 4,3 & Mild & $2-13$ & 64 & $+/-e$ \\
\hline & 241 & 2 & - & 5 & 5,5 & Moderate & $2-11$ & 32 & + \\
\hline & 244 & 4 & - & 6 & 4,8 & Moderate & $1-11$ & $>256$ & + \\
\hline & 248 & 4 & - & 6 & 4,5 & Moderate & $1-13$ & $>256$ & + \\
\hline & & & & $\bar{x} 6,2$ & & & $\bar{x} 11,5$ & & \\
\hline \multirow[t]{5}{*}{ GroupIV } & 232 & $<2$ & - & 5 & 5,3 & Moderate & $1-8$ & 32 & $+/-$ \\
\hline & 246 & $<2$ & - & 5 & 4,8 & Mild & $3-6$ & 16 & - \\
\hline & 275 & 2 & - & 6 & 3,8 & Mild & $2-6$ & 128 & - \\
\hline & 276 & $<2$ & - & 5 & 4,8 & Mild & $2-6$ & 64 & + \\
\hline & & & & $\bar{x} 5,2$ & & & $\bar{x} 5,5$ & & \\
\hline \multirow[t]{2}{*}{ GrouplV+Dx } & 237 & 2 & - & nd & nd & w/a & w/a & 2 & - \\
\hline & 242 & $<2$ & - & nd & nd & w/a & w/a & $<2$ & - \\
\hline
\end{tabular}

a VN or gE-specific antibodies in the sera of heifers at day 65 pv (before challenge);

b Heifers \# 237 and 242 were vaccinated IV and submitted to Dx administration at day 65 pv;

c Maximum virus titer (expressed as $\log _{10}$ ) detected for each particular animal;

$\mathrm{d}$ VN or gE-specific antibodies in the sera of heifers at day 30 post-challenge (pc);

e Suspicious in the gE ELISA test;

Nd: not detected;

W/a: Without clinical changes. 


\section{RESULTS}

\section{Clinical and virological findings post-vaccination}

The animals of the group IV presented a mild and transient hyperemia and edema at the inoculation sites in the days following vaccination. In general, these signs were restricted to the inoculation sites and lasted from 1 to 3 days. Three heifers developed small vesicles that rapidly erupted and healed in 2 or 3 days. Swabs collected from the inoculation sites during 2 to 6 days were positive for virus at the second passage in cell culture (titers $\leq 10^{2.97}$ $\mathrm{TCID}_{50} / \mathrm{mL}$ ). Heifers belonging to IM and control groups did not shed virus and remained healthy in the days following vaccination. These results demonstrated that the recombinant BoHV-1 strain SV265gE- is sufficiently attenuated for heifers after IV inoculation, yet it may be excreted transiently in low titers.

\section{Monitoring post-Dx administration}

Dx administration to two IV vaccinated heifers (\#237 e 242 ) at day $65 \mathrm{pv}$ did not result in virus reactivation as ascertained by failure to isolate virus from swabs collected from the inoculated sites in the days following the treatment. Likewise, no clinical recrudescence or increase in VN titers was observed after drug administration (Table 1). These results demonstrate that the recombinant vaccine strain is not easily reactivated upon Dx administration, a property that is highly desirable for a MLV vaccine of local administration.

\section{Clinical and virological findings post-challenge}

Following challenge, the animals were monitored clinically during 14 days. On a daily basis, a detailed and critical clinical examination was conducted independently by two veterinarians who were not aware of the experimental groups. The clinical examination was focused on the genital signs (listed in Material and Methods), and each aspect received a score depending on its severity. At the final of the daily examination, each veterinarian condensed the scores given to all signs and attributed a clinical score for each animal at that particular day (ranging from $(+)$ or 0,5 to ++++ or 4,0 ). Thus, an animal scored (+) had very mild signs of vulvovaginitis, the lowest degree of disease observed in the experiment. An animal scored ++++ $(4,0)$ had a very severe vulvovaginitis, showing heavy edema, pronounced congestion, widespread and coalescent pustules and wide erosions covered by a yellowish exudate.

The control heifers developed moderate (2/4) to severe (2/4) vulvovaginitis. The first signs were observed at day $2 p c$, increased in severity until days 4 and $5 p c$ and remained severe up to day 8pc (Fig.1). Then, the genital signs progressively and slowly subsided. Two animals still presented some residual signs (hyperemia, fibrinopurulent exudate) between days 11 and $14 \mathrm{pc}$. The clinical course was characterized by initial appearance of small, pinpointed pustules ( $>1 \mathrm{~mm}$ in diameter) or vesicles, surrounded by a hyperemic halo by day $2 \mathrm{pc}$. A diffuse hyperemia also appeared by days $2-3 p c$ in some animals, accompanied by

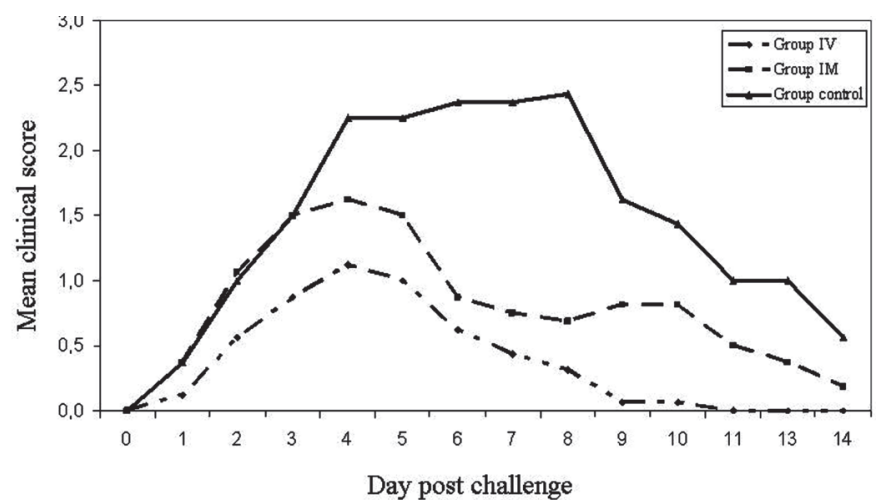

Fig.1. Mean clinical score developed after challenge (or Dx treatment) by heifers previously vaccinated (IM, IV) with the recombinant strain SV265gE- and non-vaccinated heifers.

swelling of the vulva. The pustules rapidly increased in diameter and promptly erupted, giving rise to erosions (2$3 \mathrm{~mm}$ ) covered by a yellowish exudate. The pustules tended to coalesce, originating eroded areas of variable diameter and shape covered by a fibrinopurulent exudate.

In two heifers (\# 202 and 236), these eroded areas covered by the yellowish film increased in size (by coalescence of nearby pustules) and by days 6 to 8 covered most of the internal face of the vulva. In these animals, the collection of swabs was frequently accompanied by bleeding. Animals with moderate to severe vulvovaginitis showed intense pain upon genital manipulation during examination and swab collection. In general, a discrete increase in the amount of genital secretion (serous, mucous) was observed early in the disease, giving place to a fibrinopurulent secretion which remained adhered to the lesions in late disease. A few animals presented abundant purulent secretion for one or two days during the peak of clinical disease. Swelling, hyperemia and pain were consistent findings from days 2-3 to $10-12 \mathrm{pc}$.

In the IM group, genital signs were generally milder than in the controls (with the exception of one heifer which developed moderate signs, similar to two controls) (Fig.1; Table 1). The clinical course was somehow similar, yet the clinical scores were noticeably lower than in the controls. After a peak of clinical signs between days 3 and 5, the signs subsided progressive and slowly up to days $12-13 p c$, when only reminiscent local signs could be observed. Although IM vaccination noticeably reduced the severity of disease in most animals (3/4), the duration of clinical disease was not significantly reduced because two heifers presented a delayed recovery (Table $1 ; p>0.05$ ).

Among the heifers of the IV group, three presented only mild genital signs (edema, hyperemia, small pustules) and one developed a moderate clinical disease (comparable to the IM-vaccinated heifers). The genital signs started roughly at the same time, yet did not progressed intensely as in the other experimental groups (Fig.1). The result was a disease of low severity (as measured by clinical scoring) and of significantly shorter duration (Table $1 ; p<0.05$ ) than the other groups. At day 8pc, two IV-vaccinated heifers still presented 
residual signs whereas the other two were already cured. In summary, both the severity (measured by clinical scoring) and duration (comparing the number of sick days) of genital disease were significantly reduced in the IV group, in comparison with both IM and control groups.

No significant increase in body temperature was observed during the clinical monitoring following challenge. During the peak of clinical signs, the animals hesitated to move, raised their tails laterally and urinated frequently.

After challenge, infectious virus was detected in genital secretions of control heifers during 8 to 9 days (mean: 8.2 days). Among the vaccinated heifers, virus shedding was detected during 5 to 8 days (mean: 6.2 days) in the IM group and during 5 to 6 days (mean: 5.2 days) in the IV group (Table 1 ). The length of virus shedding was significantly shorter in the IV and IM groups in comparison with controls $(p<0.05)$. The evolution of virus shedding by heifers of control and vaccinated groups is demonstrated in Fig.2.

\section{Serology}

Among the IV vaccinated heifers, two developed neutralizing antibodies detectable by VN (\#237 e 275; 4 at day $16 \mathrm{pv}$ and 2 at day $30 \mathrm{pv}$ ). The titers remained unaltered until the day of challenge (day $65 \mathrm{pv}$ ). Heifers from the IM group developed titers of 2 (two animals), 4 (one animal) and 8 (one animal) at days 16 and $30 \mathrm{pv}$. These titers remained stable until day $65 \mathrm{pv}$, with the exception of one animal which had a reduction in titer from 4 to 2 . A sentinel heifer kept in close contact with the IV group following vaccination remained seronegative throughout the experiment, so did the control heifers in the period before challenge. All vaccinated and control heifers were negative in the anti-gE ELISA performed with sera collected at day 65 pv (Table 1).

At the day of challenge, the control animals were seronegative; all heifers from IM group were positive (titers of 2 and 4); whereas only two IV vaccinated heifers had VN titers (Table 1). After challenge, a strong and rapid anamnestic response was observed in both vaccinated groups, with

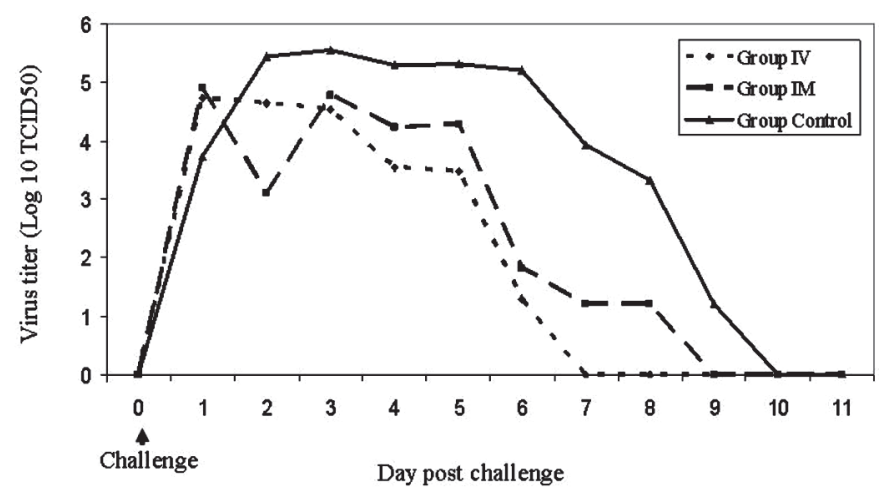

Fig.2. Virus shedding in genital secretions after challenge by heifers previously vaccinated (IM, IV) with the recombinant strain SV265gE- and non-vaccinated heifers. The mean titer for each group was calculated and is expressed as $\log _{10}$ $\mathrm{TCID}_{50}$.

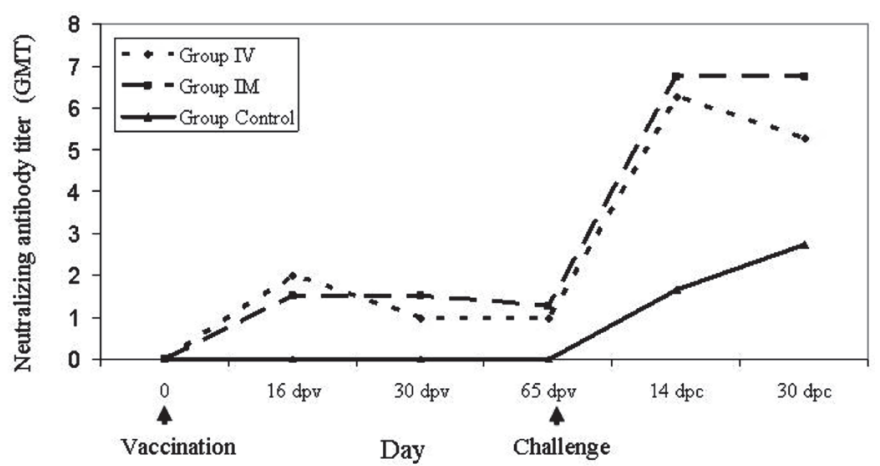

Fig.3. Virus neutralizing (VN) antibody titers to BoHV-1 in the sera of SV265gE-vaccinated (IM, IV) and control heifers. VN titers developed by individual animals were transformed in geometric mean titers (GMT) and the mean titer for each group was calculated.

the animals developing VN titers between 5 and 8 (group IM) and between 4 and 7 (group IV) at day 30pc (Fig.3). As expected, the control animals also seroconverted yet in a lower magnitude and with a certain delay in comparison with the vaccinated groups (Fig.3). The results of serology post-challenge, especially the rapid and intense anamnestic response, demonstrate that the vaccinated groups were adequately primed by vaccination. Seroconversion to $\mathrm{gE}$ was detected in 4 out of 4 controls; 3 out of 4 heifers of the IM group and 1 out 4 heifers of the IV group at day 30pc (Table 1).

\section{DISCUSSION}

Genital immunization of seronegative heifers with the recombinant, glycoprotein E-deleted Brazilian BoHV-1 strain SV265gE- conferred satisfactory clinical protection upon challenge with a highly virulent isolate. The protection in the IV-vaccinated heifers was more pronounced than in the heifers vaccinated intramuscularly, as ascertained by the magnitude and duration of virus shedding, severity and duration of clinical disease. Moreover, attempts to reactivate latent infection in two IV-vaccinated heifers by Dx administration failed, indicating that the recombinant virus does not reactivate efficiently from latency. The Brazilian SV265gE- strain has been previously shown to be attenuated for calves after intranasal (IN) and IM inoculation (Franco et al. 2002b), safe for pregnant cows (Spilki et al. 2005) and would confer clinical protection to calves upon vaccination followed by IN virus challenge (Franco et al. 2002b). Taken together, these results are promising towards the use of this recombinant strain for local immunization aiming at reducing the losses associated with BoHV-1 genital infection in the field.

Local immunization for the induction of a solid, protective immune response has long been an attractive strategy for viruses starting infection through mucosal surfaces, including BoHV-1 (Todd et al. 1971, Zygraich et al. 1975). In this sense, the induction of rapid and intense mucosal immunity is among the potential advantages of MLV BoHV1 vaccines (van Drunen Littel van den Hurk et al. 1993). IN 
immunization of calves with a MLV vaccine conferred protection within $96 \mathrm{~h}$, an effect initially attributed to interferon induction (Todd et al. 1971) yet subsequently credited also to other non-specific resistance mechanisms, secretory IgA and cell-mediated immunity (Zygraich et al. 1975, Gerber et al. 1978). Recent advances in under-standing the mucosal immune system strengthened this immunization strategy as a means to achieve both peripheral and mucosal immunity (Davis 2001). As demonstrated in human and mice, intranasal immunization may provide mucosal protection both in the nose and in the genital tract (Eriksson et al. 1998, Johansson et al. 1998).

Parenteral (IM) administration of BoHV-1 MLV vaccines also resulted in mucosal immunity and partial protection (Gerber et al. 1978); whereas intravaginal (IV) administration of a thymidine kinase-negative (tk-) BoHV1 strain resulted in both local (genital) and nasal immunity (Kit et al. 1986). In a recent study, genital administration of an adjuvanted, inactivated caprine herpesvirus 1 (CaHV1) vaccine conferred clinical protection upon genital challenge (Camero et al. 2007). Likewise, IN administration of a live attenuated glycoprotein E negative BoHV-1 vaccine to goats conferred clinical protection against genital infection by CaHV-1, a genetically and antigenically related alphaherpesvirus of goats (Thiry et al. 2006, 2007). Thus, our hypothesis was that IV immunization of heifers with a MLV, recombinant gE-deleted BoHV-1 vaccine would confer protection, in equivalent or higher levels to that achieved by IM immunization. This strategy would be especially indicated to prevent the reproductive losses associated with BoHV-1.2 genital infections.

SV265gE- immunization by both routes (IM, IV) conferred partial clinical protection following challenge with SV56/90 isolate. The challenge used in the present study has been designed as to really evaluate the protection conferred by immunization. For this, we used a heterologous BoHV-1.2 isolate previously shown to be highly virulent for bulls (Vogel et al. 2004) and heifers (Henzel et al. 2008), in a titer unlikely to be found in raw semen of infected bulls (Vogel et al. 2004) or in semen used for artificial insemination (AI) (Van Engelenburg et al. 1995). Furthermore, the virus suspension was applied by vigorous swabbing against the mucosa to assure efficient infection. Even upon a conceivably high virus titer challenge, the IV vaccinated heifers - and to a lesser extent the IM group - were satisfactorily protected from challenge. These results allow us to expect that such IV immunization would confer adequate protection to heifers upon natural challenge after sexual or Al challenge. We did not investigate a possible nasal immunity in the IVvaccinated group, yet IN protection following IV immunization has already been demonstrated for an experimental MLV, gene-deleted (tk-) BoHV-1 vaccine (Kit et al. 1986) and would be worthwhile to investigate for this recombinant strain.

The degree of protection was noticeably superior in the IV group, which shed virus in lower titers and during a significantly shorter period (5.2 days) than the IM group (6.2 days) or the controls (8.2 days). The severity and duration of clinical disease were also more pronouncedly reduced in the IV heifers in comparison with IM vaccinated animals and the controls. Two out of four IV vaccinated heifers developed only very mild and transient genital signs. The IV vaccinated heifers also presented a pronounced reduction in the duration of clinical disease (5.5 days), in comparison with IM and control groups ( 11.5 days, $\mathrm{p}<0.05)$.

Thus, IV immunization conferred satisfactory protection upon challenge, being the degree of protection higher than the protection conferred by the IM immunization with the same virus strain. It should be emphasized that the IV route utilized a $1 / 5$ of the virus dose used for IM vaccination. Although based on a limited number of experimental animals, these results are promising towards the use of this recombinant strain and this strategy of immunization. An evaluation of the impact of IV immunization on virus circulation and in the reduction of genital disease in the field, however, is still necessary before adopting the proposed immunization strategy.

The immunological basis for local protection - in a higher level than that achieved by IM vaccination - was not investigated in our experiments, yet some possible immune mechanisms can be speculated. As demonstrated in other viral systems, genital and nasal mucosa may serve as efficient sites for the induction of specific $\lg A$ and $\lg G$ responses, through priming of naïve B-lymphocytes present in the genital (or regional) lymphoid tissue (Eriksson et al. 1998, Johansson et al. 1998). Locally secreted BoHV-1-specific IgG and IgA antibodies upon re-stimulation of previously primed immune cells would then participate in the response to virus infection. In humans and guinea pigs, even nasal mucosa immunization can serve as an efficient site for the induction of specific $\lg A$ and $\lg G$ responses in vaginal secretions, probably by specific homing of antigen-primed immune $B$ and $T$ cells (McLean et al. 1996, Bergquist et al. 1997, Johansson et al. 2001). The presence of specific antibody secreting cells in the genital tract has also been demonstrated after nasal vaccination in mice (Johansson et al. 1998). The exact role of BoHV-1 antibodies in protection remains undetermined. Whereas neutralizing antibodies appear not to play a critical role in recovering from primary BoHV-1 infection, systemic (and likely locally secreted) neutralizing antibodies are believed play a relevant role in protecting and/ or limiting virus replication and spread upon reinfection (Babiuk et al. 1996). Thus, it is reasonable to assume that locally secreted antibodies (IgA, IgG) might have contributed to limit viral replication and spread following challenge, thereby contributing for the reduction of severity and duration of genital disease in IV vaccinated heifers.

The apparently weak systemic antibody response induced by IV vaccination (compared to IM immunization) - as measured by VN titers - seemed not to be detrimental for protection: the IV vaccinated heifers were satisfactorily protected compared to the control and IM-vaccinated animals. In this sense, the kinetics and magnitude of the 
antibody curve observed after challenge (typical of a secondary, anamnestic response) confirmed that both vaccinated groups were adequately primed by vaccination. In contrast, control animals responded serologically with in primary response kinetics (Fig.3). It is reasonable to consider that, in addition to locally secreted antibodies, other humoral and cell-mediated immune mechanisms such as lysis of infected cells by virus-specific cytotoxic $T$ lymphocytes, antibody-dependent cellular cytotoxicity (ADCC) by NK cells (Babiuk et al. 1996, Tikoo et al. 1995) - triggered within the genital mucosa-associated lymphoid tissue, may have also contributed to restrict virus replication and reduce the severity of clinical disease after challenge. The reduction or virus replication and shedding in the IV vaccinated heifers (thereby reducing the severity and duration of clinical signs) is consistent with a local, virus replication restrictive immune response.

Swabbing the sites of genital vaccination in the days following the procedure revealed the presence of infectious virus at low titers. Although rare after parenteral (IM, SC) administration, virus shedding is a frequently observed finding after IN and IV vaccination (Kit et al. 1986, Frerichs et al. 1982, Kaashoek et al. 1996). In our experiment, the excreted virus apparently did not suffice to assure virus transmission since a susceptible heifer kept in close contact remained seronegative. Nevertheless, vaccine virus shedding and transmission to susceptible animals might take place and thus should not be ignored if adopting genital immunization of heifers with this recombinant strain.

The use of a gE-deleted recombinant strain for genital immunization would present several advantages, including the possibility of serological differentiation of vaccinated from naturally infected animals. Although Brazil and most South American countries have not yet embarked on BoHV-1 eradication programs, the use of differential vaccines (still insipient) represents an attractive strategy for herd certification through animal trade and/or export (Brum et al. 2009). The safety and attenuation of the vaccine strain SV265gE- for calves and pregnant cows also represent an advantage over other vaccine strains available (Franco et al. 2002b; Spilki et al. 2005). In addition to an expected solid local immune response, genital immunization may also provide mucosal immunity able to protect against IN challenge (Kit et al. 1986). The failure to reactivate the latent infection and thereby be transmitted to other animals upon Dx treatment - a desirable defect demonstrated for other gE- BoHV-1 strains (Mars et al. 2000, Kaashoek et al. 1998, Liu et al. 2008, Franco et al. $2002 \mathrm{~b}$ ) - also represents an attractive property of this vaccine candidate strain. Additionally, the concept of needle-free BoHV-1 vaccines (in this case, avoiding IM or SC injections) has been strengthened lately, as to avoid muscular or subcutaneous injuries and scars that would result in reduced tenderness of the meat and/or trims at the industry resulting in economic losses (van DrunenLittel van den Hurk 2006). In summary, the concept of local immunization with an attenuated, gene-deleted strain that would allow serological differentiation should be considered as an attractive alternative to prevent genital BoHV-1 disease in the field.

Although IV immunization with the SV265gE- strain seems to represent a promising strategy for reducing virus circulation and the losses associated with genital BoHV-1 infections in the field, some aspects deserve further investigation. The risk of vaccine virus transmission during acute replication following immunization or after virus reactivation (possible yet unlikely) should not be neglected and would thus require in deep studies. The effectiveness of an IV immunization to provide protection also upon IN challenge should be studied as an alternative strategy in herds where respiratory and genital infections occur concomitantly (Pritchard et al. 1997, Kahrs 2001). The impact of genital immunization in reducing virus transmission and clinical disease under field conditions also awaits further investigation. Finally, elucidating the immunological mechanisms underlying local protection by genital vaccination would provide new and relevant insights into BoHV-1 immunology and vaccine development.

\section{REFERENCES}

Ackermann M. \& Engels M. 2006. Pro and contra IBR eradication.Vet. Microbiol. 113 (3/4):293-302.

Babiuk L.A., van Drunen Littel-van den Hurk S. \& Tikoo S.K. 1996. Immunology of bovine herpesvirus 1 infection. Vet. Microbiol. 53:31-42.

Bergquist C., Johansson E.L., Lagergard T., Holmgren J. \& Rudin A. 1997. Intranasal vaccination of humans with recombinant cholera toxin B subunit induces systemic and local antibody responses in the upper respiratory tract and the vagina. Infect Immun. 65:2676-2684.

Bratanich A.C., Sardi A.I., Smitsäart E.N. \& Schudel A.A. 1991. Comparative studies of BHV-1 variants by in vivo and in vitro tests. J. Vet. Med. B. 38:41-48.

Brum M.C., Weiblen R., Flores E.F. \& Chowdhury S.I. 2009. Construction and in vitro characterization of bovine herpesvirus type 5 recombinants defective in the glycoprotein E, thymidine kinase and both genes. Braz. J. Med. Biol.Research. (in press).

Bulach D.M. \& Studdert M.J. 1990. Comparative genome mapping of bovine encephalitis herpesvirus, bovine herpesvirus 1 and buffalo herpesvirus. Arch. Virol. 113:17-34.

Camero M., Bellacicco A.L., Tarsitano E., Decaro N., Martella V., Tempesta M. \& Buonavoglia C. 2007. Intravaginal administration of an inactivated vaccine prevents lesions induced by caprine herpesvirus1 in goats. Vaccine. 9:1658-61.

D'Arce R.C.F., Almeida R.S., Silva T.C., Franco A.C., Spilki F., Roehe P.M., Arna C.W. 2002. Restriction endonuclease and monoclonal antibodies analysis of Brazilian isolates of bovine herpesvirus types 1 and 5. Vet. Microbiol. 88:315-324.

Davis S.S. 2001. Nasal vaccines. Adv. Drug. Deliv. Rev. 51:21-42.

Eriksson K., Quiding-Jarbrink M., Osek J., Moller A., Bjork S., Holmgren J. \& Czerkinsky C. 1998. Specific-antibody-secreting cells in the rectums and genital tracts of nonhuman primates following vaccination. Infect Immun. 66:5889-5896.

Flores E.F. \& Donis R.O. 1995. Isolation of mutant MDBK cell line resistant to bovine viral diarrhea virus infection due to a block in viral entry. Virology. 208(2):565-575.

Franco A.C., Rijsewijk F.A.M., Flores E.F., Weiblen R. \& Roehe P.M. 2002a. Construction and characterization of a glycoprotein $E$ deletion mutant of bovine herpesvirus type 1.2 strain isolated in Brazil. Braz. J. Microbiol. 33(3):274-278. 
Franco A.C., Spilki F.R., Esteves P.A., Lima M., Weiblen R., Flores E.F., Weiblen R., Rijsewijk F.A. \& Roehe P.M. 2002b. A brazilian Glycoprotein E-negative bovine herpesvirus type 1.2a (BHV-1.2a) mutant is attenuated for cattle and induces protection against wildtype virus challenge. Pesq. Vet. Bras. 22(4):135-140.

Frerichs G.N., Woods S.B., Lucas M.H. \& Sands J.J. 1982. Safety and efficacy live and inactivated infectious rhinotracheitis vaccines. Vet. Rec. 111:116-122.

Gerber J.D., Marron A.E. \& Kucera C.J. 1978. Local and systemic cellular and antibody immune responses of cattle to infectious bovine rhinotracheitis virus vaccines administered intranasally or intramusculary. Am. J. Vet. Res. 39:753-760.

Henzel A., Diel D.G., Arenhart S., Vogel F.S.F., Weiblen R. \& Flores E.F. 2008. Aspectos virológicos e clínico-patológicos da infecção genital aguda e latente pelo herpesvírus bovino tipo $1.2 \mathrm{em}$ bezerras experimentalmente infectadas. Pesq. Vet. Bras. 28(3):140-148.

Johansson E.L., Rask C., Fredriksson M., Eriksson K., Czerkinsky C. \& Holmgren J. 1998. Antibodies and antibody-secreting cells in the female genital tract after vaginal or intranasal immunization with cholera toxin B subunit or conjugates. Infect. Immun. 66:514-520.

Johansson E.L, Wassen L., Holmgren J., Jertborn M. \& Rudin A. 2001. Nasal and vaginal vaccinations have differential effects on antibody responses in vaginal and cervical secretions in humans. Infect. Immun. 69:7481-7486.

Kaashoek M.J., Moerman A., Madiæ J., Weerdmeester K., MarisVeldhuis M., Rijsewijk F.A. \& Van Oirschot J.T. 1995. An inactivated vaccine based on a glycoprotein E-negative strain of bovine herpesvirus 1 induces protective immunity and allows serological differentiation. Vaccine. 13(4):342-346.

Kaashoek M.J., Van Engelenburg F.A., Moerman A., Gielkens A.L., Rijsewijk F.A. \& Van Oirschot J.T. 1996. Virulence and immunogenicity in calves of thymidine kinase- and glycoprotein E-negative bovine herpesvirus 1 mutants. Vet. Microbiol. 48(1-2):143-53.

Kaashoek M.J., Rijsewijk F.A., Ruuls R.C., Keil G.M., Thiry E., Pastoret P.P. \& Van Oirschot J.T. 1998. Virulence, immunogenicity and reactivation of bovine herpesvirus 1 mutants with a deletion in the $\mathrm{gC}$, gG, gl, gE, or in both the gl and gE gene, Vaccine. 16(8):802-809.

Kahrs R.F. 2001. Viral disease of cattle. lowa State University Press, Ames, p.159-170.

Kit S., Kit M. \& McConnell S. 1986. Intramuscular and intravaginal vaccination of pregnant cows with thymidine kinase-negative, temperature-resistant infectious bovine rhinotracheitis virus (bovine herpesvirus 1). Vaccine. 4(1):55-61.

Liu Z.F., Brum M.C.S., Doster A., Jones C. \& Chowdhury S.I. 2008. A Bovine Herpesvirus Type 1 (BHV-1) Mutant Virus Specifying a Carboxyl Terminal Truncation of Glycoprotein E (gE) is Defective in Anterograde Neuronal Transport in Rabbits and Calves. J. Virol. 82:7432-7442.

Mars M.H., de Jong M.C. \& van Oirschot J.T. 2000. A gE-negative bovine herpesvirus 1 vaccine strain is not re-excreted nor transmitted in an experimental cattle population after corticosteroid treatments. Vaccine. 18:1975-1981.

McLean C.S., Challanain D., Duncan I., Boursnell M.E.G., Jennings R. \& Inglis S.C. 1996. Induction of a protective immune response by mucosal vaccination with a DISC HSV-1 vaccine. Vaccine. 14(10):987-992.

Metzler A.E., Matile H., Gassmann U., Engels M. \& Wyler R. 1985. European isolates of bovine herpesvirus 1: Comparison of restriction endocuclease sites, polypeptides, and reactivity with monoclonal antibodies. Arch. Virol. 85:57-59.

Metzler A.E., Schudel A.A. \& Engels M. 1986. Bovine herpesvirus 1: molecular and antigenic characteristics of variant viruses isolated from calves with neurological disease. Arch. Virol. 87:205-217.
Pritchard G., Cook N. \& Banks M. 1997. Infectious pustular vulvovaginitis/ infectious pustular balanoposthitis in cattle. Vet. Rec. 140(22):587.

Reed L. \& Muench H.A. 1938. Simple method of estimating fifth percent endpoints. Am. J. Hyg. 27:493-497.

Roizman B. 1992. The family Herpesviridae: An update. Arch.Virol. 123:425-449.

Rock D.L. 1994. Latent infection with bovine herpesvirus type 1. Sem. Virol. 5(3):233-240.

Spilki F.R., Silva A.D., Batista H.B., Ruthner C., Oliveira A.P., Winkelmann E., Franco A.C., Porciúncula J.A. \& Roehe P.M. 2005. Field evaluation of safety during gestation and horizontal spread of a recombinant differential bovine herpesvirus 1 (BoHV-1) vaccine. Pesq. Vet. Bras. 25(1):54-58.

Suarez-Heilen A., Metzler A.E., Weiblen R., Berrios P., Schudel A.A. \& Rodriguez M. 1993. Molecular characterization of South American bovine herpesvirus-1 isolates with monoclonal antibodies and SDSPAGE. J. Vet. Med. B. 40:125-130.

Todd J.D., Volenec F.J. \& Paton I.M. 1971. Intranasal vaccination against infectious bovine rhinotracheitis: Studies on early onset of protection and use of the vaccine in pregnant cows. Am. Vet. Med. Assoc. 159:1370-1374.

Thiry J., Keuser V., Muylkens B., Meurens F., Gogev S., Vanderplasschen A. \& Thiry E. 2006. Ruminant alphaherpesviruses related to bovine herpesvirus 1. Vet. Res. 37:169-190.

Thiry J., Tempesta M., Camero M., Tarsitano E., Muylkens B., Meurens F., Thiry E., Buonavoglia C. 2007. Clinical protection against caprine herpesvirus 1 genital infection by intranasal administration of a live attenuated glycoprotein $\mathrm{E}$ negative bovine herpesvirus 1 vaccine. BMC Vet. Res. 5:3-33.

Thrusfield M. 1986. Veterinary epidemiology. Butterworths, London, p. 175-186.

Tikoo S.K., Campos M. \& Babiuk L.A. 1995. Bovine herpesvirus 1 (BHV1): Biology, pathogenesis and control. Adv. Virus. Res. 45:191-223.

Van Drunen Littel-van den Hurk S. 2006. Rationale and perspectives on the success of vaccination against bovine herpesvirus-1. Vet. Microbiol. 113:275-282

Van Drunen Littel-van den Hurk S., Tikoo S.K., Liang X. \& Babiuk A. 1993. Bovine herpesvirus-1 vaccines. Immunology and Cell Biology. 71:405-420.

Van Engelenburg F.A.C., Van Schie F.W., Rijsewijk F.A.M. \& Van Oirschot J.T. 1995. Excretion of bovine herpesvirus 1 in semen is detected much longer by PCR than by virus isolation. J. Clin. Microbiol. 33(2):308-312.

Vogel F.S.F., Flores E.F., Weiblen R., Winkellman E.R., Moraes M.P. \& Bragança J.F.M. 2004. Intrapreputial infection of young bulls with bovine herpesvirus type 1.2. (BHV-1.2): acute balanoposthitis, latent infection and detection of viral DNA in regional neural and non-neural tissues 50 days after experimental reactivation. Vet. Microbiol. 98(3/ 4):185-196.

Weiblen R., Kreutz L.C., Canabarro T.F., Schuch L.F. \& Rebelatto M.C. 1992. Isolation of bovine herpesvirus 1 from preputial swabs and semen of bulls with balanoposthitis. J. Vet. Diagn. Invest. 4(3):341-343.

Weiblen R., Moraes M.P., Rebelatto M.C., Lovato L.T. \& Canabarro T.F. 1996. Bovine herpesvirus isolates. Rev. Microbiol. 27(3):87-90.

Winkler M.T.C., Doster A., Jones C. 2000. Persistence and reactivation of bovine herpesvirus 1 in the tonsils of latently infected calves. J. Virol. 74(11):5337-5346

Zygraich N., Lobmann M. \& Peterhans J. 1975. Local and systemic response after simultaneous intranasal inoculation of temperaturesensitive mutants of parainfluenza-3, IBR and adenovirus 3. Dev. Boil. Stand. 28:482-488. 